\title{
Pengapusan Hak Veto Dalam Rangka Reformasi Dewan Keamanan PBB
}

\author{
Dewi Afrilianti*; Budi Ardianto; Dony Yusra Pebrianto \\ Fakultas Hukum Universitas Jambi \\ *Corresponding author: ddewiafril2204@gmail.com
}

$\begin{array}{ll}\text { Submission } & : \text { 16 Februari } 2021 \\ \text { Revision } & : 1 \text { Maret } 2021 \\ \text { Publication } & : 2 \text { Juni } 2021\end{array}$

\begin{abstract}
This study aims to find out what is the reason the veto is considered irrelevant to the Security Council in realizing world security and peace in connection with the plan of veto power in the framework of reform of the United Nations Security Council because the use of veto rights by the five permanent member states of the Security Council, especially the United States has been used with no limits. The research method used is normative type with statutory, conceptual, and case approach. The results of this study show that the security council's veto power in practice has deviated from its original intent. The reform efforts of the United Nations Security Council have many obstacles but the main obstacles that greatly hinder the reform efforts are the arrogant, selfish, and willess nature of the permanent members of the United Nations Security Council who are veto holders to continue to maintain their hegemony and national interests.
\end{abstract}

Keywords: Right; United Nations; Veto.

\begin{abstract}
Abstrak
Penelitian ini bertujuan untuk mengetahui apa yang menjadi alasan hak veto dianggap tidak relevan lagi bagi Dewan Keamanan dalam mewujudkan keamanan dan perdamaian dunia berkaitan dengan rencana Pengapusan Hak Veto pada Rangka Reformasi DK PBB karena penggunaaan hak veto oleh kelima negara anggota tetap pemegang hak veto DK PBB, terutama Amerika Serikat telah digunakan dengan tidak ada batasnya. Metode penelitian yang
\end{abstract}


digunakan adalah tipe normatif dengan pendekatan Perundangundangan, Konseptual, dan Kasus. Hasil penelitian ini menunjukkan bahwa kendala utama yang menjadi sebuah penghambat dari upaya yang dilakukan oleh negara yang menunjukkan adanya proses reformasi atau perubahan di tubuh $\mathrm{PBB}$ adalah kekuasaan istimewa berbentuk hak veto yang dimiliki oleh anggota tetap DK PBB itu sendiri, hal ini menggambarkan sebuah sifat egois, arogan serta kemauan keras mereka dalam hal untuk mengusung terlebih dahulu hegemoni serta kepentingan nasional mereka diatas kepentingan lainnya.

Kata Kunci: Hak; PBB; Veto.

\section{A. Pendahuluan}

Pada awalnya, hak veto adalah hak yang dimiliki oleh lima negara anggota tetap DK PBB ini dibahas secara detail dan teratur pada saat merumuskan Piagam PBB di Dumbarton Oaks, di Yalta, dan di San Fransisco. Bahwa lima negara tersebutlah yang akan mengemban tanggung jawab dalam penyelesaian Perang Dunia II. ${ }^{1}$

Adanya hak istimewa berupa hak veto tersebut, kekuasaan yang dimiliki oleh Tiongkok, Perancis, Inggris, Rusia, dan Amerika Serikat tidak menjadi pembeda antara negara anggota tetap dengan negara anggota DK PBB lainnya. Kewajiban dan tanggung jawab yang dimiliki oleh anggota tetap dewan keamanan tetaplah sama. Dan hal ini telah tercantum pada Piagam PBB, bahwasanya tanggung jawab utama dalam menjaga perdamaian dan keamanan dunia ada di

1 Sri Setianingsih Suwardi, Pengantar Hukum Organisasi Internasional. Cetakan 1, Universitas Indonesia, Jakarta. 2004. Hal. 291.

Uti Possidetis: Journal of International Law, Vol. 2, No. 2 (2021) 
Pengapusan Hak Veto Dalam Rangka Reformasi Dewan...

pihak Dewan Keamanan² dan bukan pada negara pemegang hak veto.

Pasal 27 ayat (1) Piagam PBB telah menentukan bahwa setiap negara yang merupakan anggota DK PBB memiliki satu suara. Pasal 27 ayat (2) Piagam PBB menyebutkan bahwa keputusan-keputusan yang dibuat DK PBB berkaitan dengan hal-hal prosedural yang diambil hasil dari suara setuju terhadap 9 anggota. Kemudian Pasal 27 ayat (3) Piagam PBB menyebutkan hasil dari keputusan DK PBB yang menyangkut hal-hal lain yang ditimbulkan hasil dari suara setuju dari 9 anggota negara DK PBB termasuk suara dari negara anggota tetap DK PBB itu sendiri, dengan ketentuan bahwa pihak yang berselisih tidak dapat ikut memberikan suara. ${ }^{3}$

Kekuatan hak veto yang hanya dimiliki oleh anggota yang memiliki hak veto pada mulanya menjadi hak istimewa untuk membantu peran Dewan Keamanan dalam fungsinya untukperdamaian dan keamanan internasional, namun kenyataannya justru tidak sesuai dengan yang diharapkan.

Akan tetapi hak veto justru dipergunakan dengan tidak semestinya, terutama Amerika Serikat yang mempergunakan hak vetonya dengan tanpa batas. Hal ini pun menjadi bukti nyata bahwa keberadaan hak veto menjadikan lima negara anggota tetap Dewan Keamanan memiliki posisi atau

2 Pasal 24 Ayat (1) Piagam PBB.

3 Pasal 27 Piagam PBB.

Uti Possidetis: Journal of International Law, Vol. 2, No. 2 (2021) 
kedaulatan lebih dibandingkan terhadap negara-negara anggota DK PBB lainnya. Tentu saja hal ini tidaksesuai atau bertentangan dengan asas persamaan kedaulatan (principle of the sovereign equality). Pendapat yang sampai saat ini berkembang di masyarakat internasional dari negara-negara berstatus negara dunia ketiga, yang mengatakan bahwa keberadaan lima negara anggota tetap Dewan Keamanan Perserikataan Bangsa-Bangsa dan hak vetonya itu perlu untuk ditinjau kembali, dengan alasan tidak lagi sesuai dengan kondisi perkembangan dunia yang sudah semakin global dan demokrasi yang semakin berkembang, mereka menganggap Dewan Keamanan tidak objektif dan lamban dalam upaya menyelesaikan sengketa internasional yang berdampak pada masalah kemanusiaan akibat terlampau sering menggunakan hak vetonya. ${ }^{4}$

Mengenai konflik bersenjata, sejak awal berdirinya PBB telah tercatat lebih dari 150 konflik bersenjata yang memakan korban jiwa. Konflik ini tidak sepenuhnya dapat ditangani oleh PBB terlebih Dewan Keamanan yang memiliki fungsi yang berkaitan langsung dengan pemeliharaan kedamaian dan keamanan internasional, hal ini menjadi pertentangan dan menjadi sumber konflik antara Blok Barat

4 Ade Ichsan Yasir Nasution, "Hak Veto Oleh Negara Anggota Tetap Dewan Keamanan PBB Dan Implikasinya Terhadap Upaya Keamanan Dan Perdamaian Dunia (Studi Kasus Konflik IsraelPalestina)" diakses dari http://repository.unpas.ac.id/562/, pada tanggal 13 Februari 2020. 
Pengapusan Hak Veto Dalam Rangka Reformasi Dewan...

dan Blok Timur yang berpengaruh terhadap keputusan internal Dewan Keamanan. Negara anggota tetap Dewan Keamanan bisa saja menggunakan hak vetonya berkali-kali tanpa batas sehingga konflik yang seharusnya bisa diselesaikan menjadi tidak bisa diselesaikan secara tuntas karena menyangkut kepentingan pribadi negara mereka. ${ }^{5}$

Beberapa contoh kasus berkaitan dengan tugas Dewan Keamanan:

1. Rusia dan Tiongkok yang memveto resolusi PBB untuk memberikan sanksi terhadap Suriah karena dugaan penggunaan senjata kimia dalam konflik Suriah. Telah tujuh kali bagi Rusia dan keenam kalinya bangi Tiongkok menggunakan hak veto-nya. Tuduhan PBB ini dibantah oleh Presiden Bashar Al-Assad namun hasil penyelidikan menunjukkan bahwa pemerintah Suriah terbukti menggunakan senjata kimia dalam tiga serangan pada tahun 2014-2015.

Akan tetapi Tiongkok menyatakan bahwa terlalu dini untuk menjatuhkan sanksi saat investigasi masih berlangsung. 6

5 Sumaryo Suryokusumo, Studi Kasus Hukum Organisasi Internasional, Cet. 1, PT Alumni, Bandung, 1997, hal. 158.

6 Citra Dewi, "Rusia dan Tiongkok Veto Resolusi PBB Terkait Konflik Suriah" diakses dari https://www.liputan6.com/global/read/287 1945/rusia-dan-Tiongkok-veto-resolusi-pbb-terkait-konflik-suri ah, pada tanggal 13 Februari 2020. 
2. Amerika Serikat memveto rancangan resolusi yang diusulkan Mesir atas rencana Presiden Amerika Serikat Donald Trump dalam pemindahan kantor kedutaan dari Tel Aviv ke Yerussalem. Ketika dibawa ke sidang Dewan Keamanan PBB mayoritas negara anggota menyatakan setuju dengan usul Mesir. Akan tetapi Amerika Serikat tidakmenyetujui hal ini dan keputusan Amerika Serikat memiliki peran strategis dalam pengambilan keputusan di PBB sebab hak veto yang dimilikinya. $^{7}$

Lima negara yang memiliki hak istimewa dan superior atas dunia dan beberapa masalah lain akibat adanya hak veto ini menimbulkan rencana dari beberapa negara untuk mereformasikan hak veto Dewan Keamanan PBB. Hal ini menjadi pertanyaan apa alasan hak veto dianggap tidak relevan lagi bagi Dewan Keamanan dalam mewujudkan keamanan dan perdamaian dunia.

\section{B. Pembahasan}

Hak veto telah ada semenjak sebelum adanya PBB, yaitu Liga Bangsa-Bangsa. Di Liga Bangsa-Bangsa, setiap negara yang memiliki hak veto terhadap keputusan non-prosedural

7 Palupi Annisa Auliani, "Amerika Veto Rancangan Resolusi DK PBB" diakses dari https://internasional.kompas.com/komentar/2017/ 12/19/03120791/amerika-veto-rancangan-resolusi-dk-pbb-soal -yerusalem, pada tanggal 13 Februari 2020.

Uti Possidetis: Journal of International Law, Vol. 2, No. 2 (2021) 
Pengapusan Hak Veto Dalam Rangka Reformasi Dewan...

menyebabkan setiap keputusan yang dihasilkan harus disetujui seluruh negara anggota.

Pada saat Liga Bangsa-Bangsa dibubarkan akibat Perang Dunia ke II, sekutu Perang Dunia II selanjutnya membentuk PBB. Amerika Serikat, Inggirs, dan Uni Soviet memprakarsai dibentuknya PBB pada bulan Agustus hingga Oktober 1944 di Dumbartoon Oaks dan pada bulan Februari 1945 di Yalta.

Kemudian Tiongkok ikut bergabung pada kepemimpinan empat negara ini dan menyepakati prinsip konsensus yang berati semua kebijakan yang harus berdasarkan persetujuan dari para pihak anggota. ${ }^{8}$

Pada awalnya hak veto diperdebatkan, hal ini tercatat sebuah Jurnal The American Political Science Review Volume 39 No. 5 yang diterbitkan pada Oktober 1945. Kemudian pada saat Konferensi San Francisco lahirnya Piagam PBB, delegasi Amerika Serikat tetap pada pendirian untukmencantumkan prinsip konsensus pada piagam. Hal ini menyebabkan protes dari Negara-negara kecil karena adanya veto yang dimiliki oleh lima negara pemrakarsa PBB.

Di Piagam PBB, pengaturan mengenai hak veto tidak diatur secara jelas. Akan tetapi pada Pasal 27 menyebutkan bahwa semua urusan prosedural Dewan Keamanan harus diputuskan secara bersama-sama oleh lima anggota tetap. Hal

8 Nibras Nada Nailufar, Hak Veto PBB: Definisi, Sejarah, dan Perdebatannya, diakses dari https://www.kompas.com/skola /read/2020/01/31/213000169/hak-veto-pbb-definisi-sejarahdan-perdebatannya?page=all, pada tanggal 02 September 2020.

Uti Possidetis: Journal of International Law, Vol. 2, No. 2 (2021) 
ini mengakibatkan apabila salah satu negara anggota pemegang hak veto tidak menyetujui maka keputusan tidakakan bisa dibuat.

Pada perkembangannya penggunaan hak veto dilakukan demi kepentingan negara pemegang hak veto itu sendiri. Hal ini terlihat dari hasil riset PBB dari tahun 1949 hingga tahun 2019, Uni Soviet yang telah berubah menjadi Rusia menggunakan hak veto yang dimilikinya sebanyak 141 kali. Disusul oleh Amerika Serikat sebanyak 83 kali, Inggris sebanyak 32 kali, Prancis 18 kali dan yang terakhir Tingkok sebanyak 14 kali.

\section{Reformasi Dewan Keamanan PBB}

Negara anggota yang memiliki hak veto terhadap keputusan Keamanan PBB mendapat kritikan dari masyarakat internasional karena seringnya menggunakan hak veto secara bebas demi kepentingan internal dari masing masing negara. Masyarakat internasional menginginkan agar ada reformasi terhadap Dewan Keamanan PBB. Beberapa negara pun ada yang menyuarakan penghapusan hak veto karena menilai hak veto yang tidak demokratis dan bahkan tidak efektif lagi untuk menyelesaikan konflik antar negara yang seringkali terjadi saat ini.

Negara yang setuju untuk dihapuskannya hak veto salah satunya ialah Indonesia. Hal ini disampaikan oleh Dirjen 
Multilateral Kemlu Hasan Kleib pada tahun 2016 lalu. ${ }^{9}$ Umumnya usulan dari negara-negara dalam reformasi DK PBB berkaitan dengan beberapa hal berkaitan dengan jenis keanggotaan, persoalan mengenai hak veto, keterwakilan dari kawasan, jumlah anggota dari DK PBB setelah adanya perluasan serta metode kerjanya dan yang terakhir berkaitan dengan hubungan antra DK dan Majelis Umum PBB itu sendiri.

Pada pembahasan reformasi hak veto DK PBB, permasalahan yang menjadi bahan perbincangan adalah masalah perluasan anggota tetap yang memiliki hak veto. Usulan ini dimulai beberapa tahun terakhir yang berasal dari kelompok Uniting for Consesus, G-4, Kelompok Afrika yang belum dapat menjembatani perbedaan nyata antara negaranegara PBB.

Uniting for consensus (UFC) merupakan bentuk dari penipakan penambahan anggota PBB yang dimulai pada era 1990. Tujuan gerakan ini berasal dari negara-negara yang merupakan anggota G4 yakni Brazil, Jerman, India dan Jepang. Dari gerakan ini terdapat tuntutan akan konsensus sebelum bentuk dan ukuran DK disetujui. ${ }^{10}$

G-4 atau Grup Empat yang merupakan sebuah aliansi antara Brazil, Jerman, India, dan Jepang dengan tujuan

9 Said Mustafa Husin, "Perlukah Penghapusan Hak Veto PBB", https://www.kompasiana.com/esemha/5a490014bde57505cb0 c20b4/perlukah-penghapusan-hak-veto-pbb?page=all (diakses pada 2 Oktober 2019).

10 Uniting For Consensus, diakses pada Wikipedia pada tanggal 3 Oktober 2019. 
untuksaling mendukung upaya satu sama lain dalam rangka memperoleh kursi permanen pada Dewan Keamanan PBB.11 Adapun ketentuan hukum yang menghambat upaya reformasi DK PBB. Terdapat landasan yang kuat dalam Piagam PBB sehingga menyulitkan upaya reformasi DK PBB . Hal ini tentu mengecewakan karena ketentuan yang telah membatasi tugas kerja dari badan tersebut dalam melakukan perubahan atas Piagam PBB. Lebih tepatnya ketentuan yang dimaksud dapat dilihat dalam Pasal 108 dan Pasal 109 dalam Bab XVIII Piagam PBB.

Pasal 108 Piagam PBB menyebutkan:

"Amendments to this Charter shall apply to all members of the United Nations if they have been accepted by a vote of twothirds of the members of the General Assembly and ratified in accordance with the statutory processes of two-thirds of the members of the United Nations. The nation includes all permanent members of the Security Council."

Pasal 109 Piagam PBB menyebutkan:

1. A General conference of members of the United Nations which intends to review the existing Charter may be held at a time and place approved by two-thirds of the votes of the members of the General Assembly as well as nine votes of any member of the Security Council of the United Nations.

11 Wikipedia, https://id.wikipedia.org/wiki/G4 diakses pada tanggal 3 Oktober 2019. 
Pengapusan Hak Veto Dalam Rangka Reformasi Dewan...

Each member of the United Nations has only one vote at this conference.

2. Any amendment to the existing Charter, agreed upon by two-thirds of the votes of the session, will take effect if it is ratified in accordance with constitutional processes by twothirds of the members of the United Nations including all permanent members of the Security Council.

3. If the aforementioned session has not been convened before the tenth annual session of the General Assembly after the entry into force of the present Charter, then the proposal to hold said session shall be included in the agenda of the session of the General Assembly of the United Nations and the session will be held if so determined by vote the majority of members of the General Assembly and the seven votes of any member of the Security Council.

Perubahan dalam Piagam PBB dalam usaha dalam reformasi DK PBB sesungguhnya sudah pernah ditempuh, tetapi perubahan tersebut hanya diamandemen terhadap penambahan negara anggota tidak tetap DK PBB, tidak bersangkutan ataupun memiliki dengan hak veto. Karenanya inilah waktunya masyarakat internasional harus memiliki upaya menekan PBB untuk melakukan perubahan terhadap dirinya, pada intinya terhadap Dewan Keamanan. ${ }^{12}$ Setelah itu ketentuan hukum berkaitan dengan upaya reformasi Dewan

\footnotetext{
12 Widagdo, Setyo. 2008, Masalah Hukum Internasional Publik, Bayu Media.
} 
Keamanan PBB diatur dalam pasal 10 Piagam PBB yang dapat dilihat sebagai berikut:

"The General Assembly may discuss all matters which fall within the scope of this Charter or which relate to the powers and functions of a body as defined in this Charter, and with the exception of the provisions of Article 12, may present recommendations to members of the United Nations. or the Security Council or to both bodies regarding all such matters and matters."

Pasal 110 Bab XIX Piagam PBB tentang pengesahan atau Ratifikasi dan Penanda Tanganan, yang berisi sebagai berikut:

1. This Charter shall be ratified by the signatory States in accordance with their respective constitutional processes.

2. Ratifications shall be deposited with the Government of the United States of America, which will notify each of these deposits to all signatory States and to the Secretary-General of the Organization when appointed.

Hal ini berarti bahwa sistem hukum atas usaha reformasi DK PBB diharuskan melewati beberapa prosedur yang ditetapkan dalam Piagam PBB dengan cara merubah atau mengamandemen Piagam PBB. Prosedurnya dilakukan dengan cara-cara mengajukan usulan perubahan atas hak Veto di depan hadapan Majelis Umum PBB untuk mendapatkan sekutu mengenai dalam upaya terhadap suara dari dua pertiga anggota Majelis Umum PBB. Hal itu harus di sahkan ataupun 
Pengapusan Hak Veto Dalam Rangka Reformasi Dewan...

diratifikasi oleh 2/3 negara anggota PBB termasuk semua anggota tetap DK PBB agar dapat ditetapkan.

\section{Kendala Reformasi DK PBB}

Dapat dilihat bahwa hak veto yang dimiliki oleh lima negara anggota tetap DK PBB merupakan hal yang menjadi penghambat terhadap upaya reformasi DK. Di setiap perubahan yang fundamental, salah satunya contoh dari kursi negara DK yang tertulis secara jelas pada Piagam PBB. Lain halnya pada Pasal 109 dan 109 Piagam PBB telah menetapkan hak veto terhadap 5 negara yang menjadi anggota tetap pada setiap perubahan ataupun amandemen pada Piagam PBB. Hal itu menjadi jelas pada setiap perubahan pada PBB tidak akan terwujud tanpa kesepakatan dari negara anggota DK.

Salah satu contohnya, Tiongkok sebagai negara dengan hak veto DK PBB menolak terhadap usulan tambahan anggota tetap. Hal ini menyebabkan anggota G-4 yang menjadi pendukung dari perubahan ini tidak akan memiliki kesempatan terhadap proses perubahan ini. Cina secara aktif menentang bagian dari usulan perubahan tersebut. Oleh karena itu, seorang sejarawan yang berasal dari Universitas Yale, Paul Kennedy, menyebut hak veto merupakan "The Catch-22" dari perubahan terhadap Piagam PBB.

Istilah The Catch-22 adalah istilah yang sering dipakai untuk menjelaskan suatu hasil ataupun solusi dari apa yang diinginkan yang tidak mungkin ataupun mustahil untuk 
dicapai karena situasi atau keadaan yang tidak dapat dianggap logis dan adil. Pada Pasal 108 serta 109 Piagam PBB yang membuat prospek reformasi hak veto menjadi sangat riskan, dan hampir dilihat mejadi hal yang mustahil. Hal ini menyebabkan sulit untuk mengharapkan bahwa terhadap pihak yang memiliki hak veto untuk ikut serta menyetujui setiap langkah perubahan terhadap hak veto yang menyebabkan para pihak yang memiliki hak tersebut memiliki kendali yang penting dalam organ PBB. Pada kenyataannya Piagam PBB menyebabkan negara anggota tetap DK PBB yang merupakan pemegang hak veto tersebut untuk menjengkal setiap usulan perubahan yang diharapkan kepada DK PBB yang dapat mengacaukan kendali mereka dalam organ PBB. ${ }^{13}$

Hal ini menyebabkan perubahan juga akan dihalangi oleh keinginan keras dari negara pemilik hak veto dengan kepemilikan hak istimewa yang mereka pegang, terdapat kepentingan yang cukup strategis dan terus berkembang, serta kurang terbukanya pandangan terhadap para negara pemegang hak veto. Ketidakberhasilan dalam usulan perubahan DK PBB menyebabkan timbulnya pertanyaan yang cukup berbahaya terhadap sejarah yang kita alami yakni teruskah kita menunggu dan melihat keadaan yang tidak berubah ini untuk terus berlanjt hingga terjadi kerusakan

13 Sahar Okhovat, The United Nations Security Council: Its Veto Power and Its Reform, hal. 43-44.

Uti Possidetis: Journal of International Law, Vol. 2, No. 2 (2021) 
Pengapusan Hak Veto Dalam Rangka Reformasi Dewan...

serta kehancuran yang diakibatkan dari ketidakadilan yang dihasilkan kebijakan ini.

Pada pembahasan yang lalu, ketentuan Piagam PBB mengharuskan kesepatan dari semua negara anggota tetap DK PBB terhadap setiap usaha serta usulan terhadap perubahan yang telah terbukti menghambat perubahan besar pada organ itu sendiri. Akan tetapi di antara lima negara anggota tetap DK PBB, Amerika Serikat yang memiliki permasalahan yang cukup berbeda dengan rekan sesama negara anggota tetap DK PBB. Contohnya pada kasus perang di Irak pada 2003 serta gertak yang dilakukan oleh Amerika Serikat terkait sponsor keuangan pada lembaga yang bersifat internasional sekelas PBB yang menerima pendanaan dari negara adidaya tersebut terkait pengakuan adanya negara Palestina, hal ini dapat dilihat bahwa Amerika Serikat memiliki kekuasaan untuk menggerakkan arah keputusan PBB serta badan-badan lain yang tidaks esuai dengan kepentingannya. ${ }^{14}$

Menurut Thomas Weiss terdapat kebijakan dalam dan luar negeri Washington yang memiliki kendali yang luas terhadap kegiatan dan langkah dari anggota DK PBB. Hal ini diakibatkan dampak dari sepak terjang Amerika Serikat, yang terdapat pandangan yang menjadi umum yang menyebutkan bahwa negara adidaya ini akan terus ikut andil secara politik maupun keuangan pada sebuah institusi dalam menghambat institusi tersebut yang telah membatasi kekuasaan dari negara

14 Ibid.

Uti Possidetis: Journal of International Law, Vol. 2, No. 2 (2021) 
adidaya tersebut. Hal ini menyebabkan peran Amerika Serikat sebagai negara pemegang hak veto DK PBB paling pengambat terhadap perubahan dan upaya reformasi dari DK PBB. Tidak sekedar menolak negosiasi, Amerika Serikat juga dapat menarik diri dari DK PBB ataupun dari PBB itu sendiri apabila negara anggota DK PBB lain tidak sepakat dengan kepentingan nasional serta melakukan perubahan ataupun reformasi dari DK PBB.

Pada kenyataannya Amerika Serikat telah kehilangan beberapa bagian dari kendali serta kekuasaannya, yang paling utama pada sektor ekonomi, tetapi Amerika Serikat karena masih dianggap sebagai negara super power. hal tersebut dialami kepada negar anggota tetap DK PBB lainnya, yaitu Perancis, Inggris, dan Rusia. Pada saat Uni Soviet berpisah menjadi Rusia, identitas dan status yang dimilikinya telah berubah dari status sebagai sebuah negara adidaya menjadi negara yang berkeinginan atau bercita-cita untuk menjadi bagian dari kekuatan dunia. Hal itu menyebabkan Rusia tidak memiliki upaya yang sama seperti Uni Soviet sebagai negara pendahulunya. Rusia sebagai negara sudah tidak sekuat Uni Soviet begitupn dengan kekuatan ekonominya hanya sebagian dari kekuatan ekonomi Uni Soviet. Hal ini pun berlaku untuk Prancis dan Inggris yang tidak lagi memiliki kekuatan yang besar sebagaimana masa jayanya dahulu.

Yang menjadi pertanyaan adalah apakah negara anggota tetap DK PBB lain selain Amerika Serikat mau melakukan 
negosiasi? Para ahli berpendapat bahwa terjadi kasus yang berbeda dari hal ini. Negara anggota tetap DK PBB selain Amerika Serikat ini tetap mempertimbangkan ketentuan status kekuatan yang dimilikinya saat ini dan menjadi sebuah kenyataan bahwa negara-negara anggota tetap DK PBB tersebut menjadikan lembaga yang ada untuk berupaya memenuhi kepentingan nasional mereka, Thomas Weiss mengisyaratkan bahwa adanya kesempatan dalam mengurangi power yang dimiliki Inggris dan Prancis yang membuat mereka menggunakan kekuatan yang mereka miliki tersebut atau bekerja sama dengan negara lain yang sesuai dengan tujuan dari negara tersebut.

Hingga akhirnya, status negara anggota tetap DK PBB yang memiliki hak veto menjadikan mereka memiliki hak istimewa berupa kekuasaan dan kekuatan dalam mengendalikan PBB ataupun dunia internasional meskipun akhirnya hal tersebut tidak sesuai dengan kekuatan mereka yang mereka miliki pada saat ini. Terdapat pendapat bahwa status sebagai negara besar menyebabkan mereka berhati-hati untuk menentukan sikap dan langkah dalam setiap perundingan berkaitan dengan kepentingan dari negaranya. 15 Pada lain sisi, Jhon Langmore berkeyakinan mereka bersedia untuk negosisasi ataupun melakukan perundingan guna menunjukkan fleksibilitas mereka serta mencoba untuk tetap

15 Ibid.

Uti Possidetis: Journal of International Law, Vol. 2, No. 2 (2021) 
mempertahankan posisi mereka, kekuasaan dan status dengan upaya tersebut. ${ }^{16}$

Kesediaan negara anggota tetap DK PBB dalam mendorong upaya perubahan atau reformasi yang berpengaruh terhadap status dan kekuasaan yang mereka miliki di DK PBB disebbakan dari sikap yang mereka tampilkan dalam resolusi yang diusulkan negara anggota G-4. Resolusi ini merupakan upaya yang ditemph untuk melakukan perubahan yang direncanakan sejak lama. Namun tetap harus diingat baha usulan perubahan ini tidak ditujukan untuk membahayakan kekuatan dari lima negara anggota tetap DK PBB disebabkan resolusi ini tidak menyerukan reformasi atau usulan perubahan terhadap hak veto dan kabur pada hal yang berkaitan dengan jenis kursi tambahan yang diminta.

Stewart M. Patrick berpendapat bahwa Prancis dan Inggris memahami posisi mereka yang rentan dalam usaha untuk reformasi ini "sebagai fenomena pergeseran dan kemunculan kekuatan baru dunia", mendukung perubahan ini. Rusia sebagai negara yang pada mulanya sangat menentang gagasan penambahan kursi negara anggota tetap DK PBB, akhirnya ikut mensupport India dalam hal memperoleh status keanggotaan tetap pada 2010 silam. Hal ini mengakibatkan Rusia akan lebih mendukung upaya perubahan dari kelompok G-4. Sedangkan Tiongkok, walaupun sangat keras menunjukkan sikap menentang pada proposal G-4 serta

16 Ibid.

Uti Possidetis: Journal of International Law, Vol. 2, No. 2 (2021) 
Pengapusan Hak Veto Dalam Rangka Reformasi Dewan...

sekarang mencoba untuk meloby negara-negara Afrika agar tidak memberikan dukungan mereka terhadap kelompok G-4, hal ini disebabkan karena negara-negara di benua Afrika yang telah diketahui merupakan kubu yang berlawanan pada resolusi yang diusulkan oleh negara anggota G-4 ini tampaknya telah memberikan dukungan dikarenakan terdapat kepentingan Tiongkok dalam hal ini. Amerika Serikat walaupun mendukung Brazil, Jepang, dan India, tetap tidak menujukkan usaha dalam hal ini dan dukungan Amerika Serikat itu tampaknya hanya retorika semata tanpa usaha yang nyata. Pada kenyataannya tindakan nyata dari Amerika Serikat masih belum terbuka untuk mendukung usulan perubahan atau resolusi yang diajukan oleh negara anggota G-4 dan ini tampak pada saat Amerika Serikat masih bersikap ragu-ragu dalam memberikan dukungannya secara utuh dan serius pada upaya yang dilakukan oleh kelompok G-4 dan upaya reformasi lainnya. ${ }^{17}$

Yang menjadi kendala lain yang cukup serius adalah apa yang terjadi dalam perdebatan berkaitan usulan perubahan atau reformasi yakni tidak ada kesepakatan diantara negara anggota PBB mengenai rincian usulan perubahan yang diusulkan. Realita mengatakan bahwa negara-negara tidak dapat mencapai kesepakan tentang jumlah kursi tambahan di Dewan Keamanan, jenis kursi tersebut baik itu bersifat tetap ataupun tidak tetap, negara calon anggota tetap DK PBB, dan

17 Ibid.

Uti Possidetis: Journal of International Law, Vol. 2, No. 2 (2021) 
perluasan hak veto atau penghapusannya. Dan pada kenyataannya terdapat fakta yang menyatakan bahwa negara masih mendukung beberapa usulan awal mereka sendiri tanpa banyak melakukan kompromi, telah terbukti menimbulkan hambatan besar terhadap kemajuan proses perundingan reformasi. ${ }^{18}$

Pada kesimpulannya, selain yang disebutkan diatas, ada faktor lain yang menyebabkan gagalnya reformasi Dewan Keamanan PBB, diantaranya:

a. Amerika Serikat merupakan sebuah adidaya tunggal dan merupakan negara yang membiayai $25 \%$ operasional lembaga PBB tersebut nyatanya tidak memberikan lampu hijau terhadap reformasi ataupun perubahan struktural di Dewan Keamanan Perserikata Bangsa-Bangsa, sebab bagi Amerika Serikat, PBB yang merupakan sebuah organisasi internasional yang menjadi sebuah alat untuk mencapai kepentingan nasional Amerika Serikat. Dengan bergantung secara finansial PBB dari Amerika Serikat, maka organisasi internasional ini mungkin tidak independen saat mereka berhadapan dengan kepentingan Amerika Serikat dan sekutunya. Belum lagi Sekretariat PBB berada di Amerika Serikat dan sebagian besar pekerja di organisasi internasional ini adalah warga negara Amerika Serikat, sehingga lengkaplah sudah terpenuhinya Amerika Serikat

18 Ibid.

Uti Possidetis: Journal of International Law, Vol. 2, No. 2 (2021) 
Pengapusan Hak Veto Dalam Rangka Reformasi Dewan...

ini terhadap lembaga internasional yang paling bergengsi. ${ }^{19}$

b. Tiongkok yang merupakan suatu entitas sebagai anggota tetap DK PBB yang merupakan perwakilan dari dunia ketiga ternyata tidak mau berbagi kekuasaan dengan negara lain. Kepentingan Tiongkok jika Jepang menjadi anggota tetap DK PBB karena kekuatan ekonomi dan teknologinya, maka power yang dimiliki Tiongkok akan berkurang serta menjadi saingan yang kuat. Terlebih sepanjang sejarah peradaban bangsa Tiongkok dengan Jepang selalu bersaing untuk menjadi pusatnya Asia dan Dunia. Sikap konservatif Tiongkok sebetulnya sangat disesalkan sebab dunia saat ini membutuhkan kekuatan yang dapat menjadi penyeimbang Amerika Serikat yang suka berbuat unilateral dan suka meninggalkan PBB .

c. Negara-negara yang berada di benua Afrika yang baru merdeka di abad 20 ternyata tidak memiliki kekuatan yang cukup untuk menyamai negara-negara barat. Selain dipengaruhi oleh kemiskinan, kurangnya sumber daya manusia, perang saudara dan faktor lainnya, negaranegara Afrika tidak terlalu bersatu di bidang ekonomi dan mendukung rezim yang berkuasa, serta sangat bergantung pada negara-negara maju.

d. Negara-negara Eropa seperti Prancis dan Inggris khawatir Jerman akan menjadi anggota tetap Dewan Keamanan

19 Ibid.

Uti Possidetis: Journal of International Law, Vol. 2, No. 2 (2021) 
PBB. Jerman, yang pernah menguasai Eropa di bawah Nazi, masih menjadi "hantu" di sebagian besar negara Eropa.

e. Setelah hancurnya Uni Soviet, Islam gagal bersatu sebagai kekuatan alternatif untuk "menantang" Barat. Negara Islam selalu mengutamakan kepentingan nasionalnya dalam hubungan internasional, sehingga posisi negosiasinya sangat lemah. ${ }^{20}$

Oleh karena itu, kegagalan reformasi Dewan Keamanan PBB yang telah diusung oleh sebagian besar negara anggota PBB terutama diakibatkan oleh kurangnya persatuan negara baru di perundingan mengenai reformasi ataupun perubahan ini. Akibatnya dapat ditarik kesimpulan bahwa prinsip persamaan kedaulatan belum menjadi nyata dalam hal pengambilan keputusan Dewan Keamanan PBB, karena segala upaya reformasi di tubuh DK PBB, sebab negara anggota tetap DK PBB seperti Amerika Serikat serta para negara anggota lainnya yang memiliki hak veto itu sendiri telah memveto upaya yang diusung dalam hal reformasi DK PBB.

\section{Penutup}

Besarnya harapan masyarakat internasional agar DK PBB mampu menjaga perdamaian dunia sekaligus mampu menyelesaikan konflik bersenjata yang terjadi dimanapun tanpa mengutamakan kepentingan internal dalam segi apapun.

20 Widagdo, Setyo. 2008, Masalah Hukum Internasional Publik, Bayu Media

Uti Possidetis: Journal of International Law, Vol. 2, No. 2 (2021) 
Pengapusan Hak Veto Dalam Rangka Reformasi Dewan...

Hak veto tersebut semula digunakan sebagai alat agar Dewan Keamanan memiliki kekuatan yang cukup, namun justru melenceng dari niat semula. Ternyata lima anggota tetap Dewan Keamanan, terutama Amerika Serikat, telah menggunakan hak veto tanpa batas. Oleh karena itu, lebih jauh ditekankan bahwa konsep hak veto memungkinkan lima anggota tetap Dewan Keamanan PBB untuk menikmati status atau kedaulatan yang lebih tinggi dibandingkan dengan negara anggota PBB lainnya. Tentu hal ini bertentangan dengan prinsip persamaan kedaulatan (principal of the sovereign equality).

Ada banyak kendala dalam reformasi DK PBB, namun kendala utama / utama yang menjadi sebuah penghambat dari upaya yang dilakukan oleh negara yang menuntuk adanya proses reformasi atau perubahan di tubuh PBB adalah kekuasaan istimewa berbentuk hak veto yang dimiliki oleh anggota tetap DK PBB itu sendiri, hal ini menggambarkan sebuah sifat egois, arogan serta kemauan keras mereka dalam hal untuk mengusung terlebih dahulu hegemoni serta kepentingan nasional mereka diatas kepentingan lainnya. Selain itu juga pada Piagam PBB yang memberikan keuntungan dan kekuasaan terhadap negara yang memegang hak veto, pada kesimpulannya telah menjadi penghalang terhadap kesempatan untuk mereformasi lembaga ini. Jika negara-negara yang memiliki hak veto ikut serta dengan upaya memperbaiki dari DK PBB berbentuk reformasi yang selama 
ini digaungkan, maka proses ini tidak akan rumit seperti yang telah terjadi pada saat ini.

\section{Referensi}

\section{Instrumen Hukum}

Piagam PBB

Prosedur Sementara (Provisional Rules of Procedure) Dewan Keamanan PBB

\section{Buku}

Mauna, Boer, 2003, Hukum Internasional, Alumni, Bandung. Okhovat, Sahar, 2011, The United Nations Security Council: Its Veto Power and Its Reform, CPACS Working Paper No. 15. Sydney University.

Suryokusumo, Sumaryo, 2004, Studi Kasus Hukum Organisasi Internasional, Cetakan 1, PT. Alumni, Bandung.

Suwardi, Sri Setyaningsih, 2004, Pengantar Hukum Organisasi Internasional. Cetakan 1, Universitas Indonesia, Jakarta.

Widagdo, Setyo. 2008, Masalah Hukum Internasional Publik, Bayu Media, Malang.

\section{Jurnal/Artikel/Karya Ilmiah}

Ade Ichsan Yasir Nasution, "Hak Veto Oleh Negara Anggota Tetap Dewan Keamanan PBB Dan Implikasinya Terhadap Upaya Keamanan Dan Perdamaian Dunia (Studi Kasus Konflik Israel-Palestina)" diakses dari http://repository.unpas.ac.id/562/, pada tanggal 13 Februari 2020.

\section{Website}


Citra Dewi, "Rusia dan Tiongkok Veto Resolusi PBB Terkait Konflik Suriah" diakses dari https://www.liputan6.com/ global/read/2871945/rusia-dan-Tiongkok-veto-resolu si-pbb-terkait-konflik-suriah, pada tanggal 13 Februari 2020.

Nibras Nada Nailufar, Hak Veto PBB: Definisi, Sejarah, dan Perdebatannya, diakses dari https://www.kompas.com/ skola/read/2020/01/31/213000169/hak-veto-pbb-de finisi-sejarah-dan-perdebatannya?page=all,pada tanggal 02 September 2020.

Palupi Annisa Auliani, "Amerika Veto Rancangan Resolusi DK $P B B$ " diakses dari https://internasional.kompas.com/ko mentar/2017/12/19/03120791/amerika-veto-rancang an-resolusi-dk-pbb-soal-yerusalem, pada tanggal 13 Februari 2020.

Said Mustafa Husin, "Perlukah Penghapusan Hak Veto PBB", https://www.kompasiana.com/esemha/5a490014bde5 7505cb0c20b4/perlukah-penghapusan-hak-veto-pbb?p age=all (diakses pada 2 Oktober 2019).

G4 (Grup Empat) https://id.wikipedia.org/wiki/G4 diakses pada tanggal 3 Oktober 2019. 